\title{
Exposure to Low Dose of Cinnabar (a Naturally Occurring Mercuric Sulfide (HgS)) Caused Neurotoxicological Effects in Offspring Mice
}

\author{
Chun-Fa Huang, ${ }^{1,2}$ Chuan-Jen Hsu, ${ }^{3}$ Shing-Hwa Liu, ${ }^{2}$ and Shoei-Yn Lin-Shiau ${ }^{4}$ \\ ${ }^{1}$ School of Chinese Medicine, College of Chinese Medicine, China Medical University, No. 91 Hsueh-Shih Road, Taichung 404, Taiwan \\ ${ }^{2}$ Institute of Toxicology, College of Medicine, National Taiwan University, No. 1, Section 1, Jen-Ai Road, Taipei 100, Taiwan \\ ${ }^{3}$ Department of Otolaryngology, College of Medicine, National Taiwan University, No. 1, Section 1, Jen-Ai Road, Taipei 100, Taiwan \\ ${ }^{4}$ Institute of Pharmacology, College of Medicine, National Taiwan University, No. 1, Section 1, Jen-Ai Road, Taipei 100, Taiwan
}

Correspondence should be addressed to Shoei-Yn Lin-Shiau, syshiau@ntu.edu.tw

Received 6 April 2012; Accepted 24 May 2012

Academic Editor: Marcelo Farina

Copyright (C) 2012 Chun-Fa Huang et al. This is an open access article distributed under the Creative Commons Attribution License, which permits unrestricted use, distribution, and reproduction in any medium, provided the original work is properly cited.

\begin{abstract}
Cinnabar, a naturally occurring mercuric sulfide (HgS), has long been used in Chinese mineral medicine for more than 2000 years. Although mercury is well-known for its toxicity, whether cinnabar induces neurotoxicity, especially in infants and children, is unknown. The purpose of this study was to explore the neurotoxic effects of low-dose of cinnabar $(10 \mathrm{mg} / \mathrm{kg} / \mathrm{day})$ on developing mice. The results revealed neurobehavioral defects in F1-C-Cin group, which were associated with $\mathrm{Hg}$ accumulation, increased $\mathrm{NO}_{x}$ levels in whole blood, and $\mathrm{Na}^{+} / \mathrm{K}^{+}$-ATPase activities in brain tissues. F1- and F2-Cin-V groups were found to increase brain $\mathrm{Hg}$ contents and prominent neurobehavioral defects compared with $\mathrm{F} 1-\mathrm{C}-\mathrm{V}$ group, suggesting that the fetal brain was more susceptible to irreversible effects for cinnabar-induced damage. Moreover, F1- and F2-Cin-Cin groups had severely neurobehavioral dysfunctions, closely correlated with the further alteration of $\mathrm{NO}_{x}$ levels and $\mathrm{Na}^{+} / \mathrm{K}^{+}$-ATPase activities than F1and F2-C-Cin groups. Effects in F2-Cin-Cin group were more significant than those in F1-Cin-Cin group. In conclusion, this study demonstrates that exposure to low-dose of cinnabar during the perinatal and developmental stages results in irreversible and severe injuries of the neurotoxicity in offspring, and $\mathrm{NO}_{x}$ and $\mathrm{Na}^{+} / \mathrm{K}^{+}$-ATPase activities may exist potential and useful biomarkers for neurotoxicity-induced by low-doses of mercuric compounds.
\end{abstract}

\section{Introduction}

Mercury is a toxic metal that is widespread in the environment and harmful to human and mammalian. The different chemical forms (organic and inorganic) of mercurial compounds exhibit different degrees of toxicity with effects including hearing loss, vision disturbance, motor deficits, and retarded or abnormal walking ability $[1,2]$. Cinnabar (an inorganic mercurial compound) contains more than 95\% mercury sulfide ( $\mathrm{HgS})$ and has been used for many thousands of years in traditional Chinese medicine (TCM) and in Asian and Middle Eastern countries as a sedative and hypnotic [3-6]. Although cinnabar is supposed to have many therapeutic properties and is generally disregarded to result in significant mercury absorption from the gastrointestinal (G-I) tract following oral administration, its high mercury content highlights the need for studies on its possible toxic effects. Various reports have reported that cinnabar can be absorbed following oral administration at high doses and accumulated in the brain and other tissues, causing mercury intoxication $[5,7,8]$. Many studies have reported that the total amount of mercury accumulated in tissues from methylmercuric chloride $(\mathrm{MeHgCl})$ was about 5000-fold higher than that from $\mathrm{HgS}$ [9], but that exposure to a highdose of cinnabar or $\mathrm{HgS}(1.0 \mathrm{~g} / \mathrm{kg} /$ day, for 7 or 14 consecutive days) was able to cause neurotoxicity, including dysfunction of the vestibule-ocular reflex (VOR) system, an abnormal of auditory brainstem response, learning memory deficits, 
impairment of spontaneous locomotor activity, and suppression of compound muscle action potentials (CMAPs), as has been reported for $\mathrm{MeHg}$ [10-12]. Recently, Huang et al. [13] also reported that long-term exposure to low dose of cinnabar $(10 \mathrm{mg} / \mathrm{kg} /$ day, for more than 77 consecutive days) induced neurotoxicological effects, which were associated with significant $\mathrm{Hg}$ accumulation in the brain. Moreover, cinnabar-containing TCMs, such as Ba Paul San, which is used as a sedative and for the management of external infections in infants and children, have been reported to contain excess amounts of cinnabar that cause occasional intoxication in the Chinese population $[3,9,14]$. Therefore, expectant infants and children exposed to cinnabar may cause toxic effects because of overdosage and long-term administration. Nonetheless, available data on the toxicological effects and action mechanisms of cinnabar in children at the perinatal stage exposed to low doses are still insufficient.

Auditory brainstem response (ABR) test, a method to provide a clear and reliable indicator of hearing function in the central auditory system, is a useful indicator of neurotoxicity in body burdens of toxic metals $[15,16]$. It has been demonstrated the significant correlation between the abnormal ABR test (the hearing loss and the latency of wave III and V delayed) and Hg accumulation during prenatal, postnatal, development, adult stage exposed to mercury or existed in patients with mercury-contaminated area $[2,17-$ 20]. In experimental animals, the irreversible loss of hearing after exposure to chemicals (such as $\mathrm{MeHg}$ or cisplatin) has been reported to be associated with toxicity to the central auditory system, including auditory loss or damage to the cochlea $[16,21,22]$. However, possible ototoxic effects of low dose of cinnabar exposure remain unclear, especially during the perinatal or developmental periods.

On the other hand, it has been shown that chronic mercury intoxication is characterized by inhibition of neuronal $\mathrm{Na}^{+} / \mathrm{K}^{+}$-ATPase, which is a key enzyme for neurological function $[23,24] . \mathrm{Na}^{+} / \mathrm{K}^{+}$-ATPase of the neuronal membranes, which is responsible for the active transport of sodium and potassium ions in the nervous system, plays a critical role in the maintenance of cellular ionic homeostasis and in the physiological function of the inner ear as well as the nervous system $[25,26]$. The inactivation of $\mathrm{Na}^{+} / \mathrm{K}^{+}-$ ATPase leads to partial membrane depolarization, which allows excessive $\mathrm{Ca}^{2+}$ entry into neurons with resultant toxic events similar to excitotoxicity and has been implicated in pathological and physiological abnormalities and neurodegenerative diseases [26-28]. Recently, the accumulated evidence has revealed that mercurial compounds specifically bind to this enzyme and cause cell or organ dysfunction $[10,21,22,29,30]$.

Based on these findings, we attempted through this study to clarify the toxicological effects of low dose of cinnabar in offspring that were exposed after weaning, only during the perinatal and weaning stages, or across all these stages. Subsequently, we verified the working hypothesis that longterm exposure to low dose of cinnabar induced neurobehavioral abnormalities and central auditory system dysfunction through interference with $\mathrm{Na}^{+} / \mathrm{K}^{+}$-ATPase activities. We, therefore, examined a low dosage of cinnabar $(10 \mathrm{mg} / \mathrm{kg} / \mathrm{day})$ and a longer duration (7 weeks) of oral application in mice and then monitored various neurobehavioral effects (including spontaneous locomotor activities, pentobarbitalinduced sleeping time, and motor equilibrium performance) and hearing function (by ABR test, a useful parameter for indicating mercuric compounds-induced oto-toxicity), followed by analyzing changes in the $\mathrm{Hg}$ content and $\mathrm{Na}^{+} / \mathrm{K}^{+}$-ATPase activities of the brain tissues and $\mathrm{NO}_{x}$ levels of whole blood at the end of the treatment.

\section{Materials and Methods}

2.1. Animal Preparation. Randomly bred, male and female ICR mice were obtained from the Animal Center of the College of Medical, National Taiwan University (Taipei, Taiwan). The protocol was approved by the Institutional Animal Care and Use Committee (IACUC), and the care and use of laboratory animals were conducted in accordance with the guidelines of the Animal Research Committee of College of Medicine, National Taiwan University. Mice were housed seven per cage under standard laboratory conditions at a constant temperature $\left(23 \pm 2^{\circ} \mathrm{C}\right), 50 \pm 20 \%$ relative humidity, given a solid diet and tap water ad libitum and $12 \mathrm{hrs}$ for light-dark cycles. Mice were acclimatized to the laboratory conditions prior to the experiments, and all experiments were carried out between 8:00 AM and 05:00 PM. The adult male and female ICR mice $(4 \sim 5$ weeks old, 22-25 g) (breeders of F0 and F1 generations) were randomly assigned to four initial dosing groups and then were orally gavaged distilled water or $10 \mathrm{mg} / \mathrm{kg} / \mathrm{day}$ cinnabar for 4 consecutive weeks before mating, and then two females were placed per cage with one male breeder for mating. Gestational day 0 (GD 0 ) was confirmed by the presence of a vaginal plug in the morning. At that time, the female mice with vaginal plugs (dams) were placed into individual cage form GD0 to postnatal day (PND) 21 (lactation period) and then maintained exposure to cinnabar. Thus, the exclusive route of offspring exposure to mercury was through maternal milk [31]. At postnatal day (PND) 0, the offspring newborn mice (pups) were recorded the number in the litter and randomly selected from different litters (three or four per litter) and sacrificed after deep anesthesia by an intraperitoneal injection of pentobarbital $(80 \mathrm{mg} / \mathrm{kg})$, and whole blood samples of the mothers were collected to eppendorf from an eyehole vessel after light anesthesia by an intraperitoneal injection of pentobarbital $(50 \mathrm{mg} / \mathrm{kg})$. These samples were analyzed $\mathrm{Hg}$ contents. At PND 21, offspring (pups) within the original dose group assignment were randomly separated into two groups (seven per cage, total numbers $=12-15 /$ group) and then orally gavaged with distilled water or $10 \mathrm{mg} / \mathrm{kg} /$ day cinnabar for 7 consecutive weeks, respectively. Figure 1 illustrates the time course of administration of cinnabar $(10 \mathrm{mg} / \mathrm{kg} / \mathrm{day})$ to offspring and distilled water exposure during maternal gestation and weaning or following weaning. After the end of experiment, all experimental animals were sacrificed by decapitation under pentobarbital anesthesia $(80 \mathrm{mg} / \mathrm{kg}$, i.p.) after administration with the vehicle control or cinnabar fed. Various tissues were quickly removed to liquid nitrogen and 

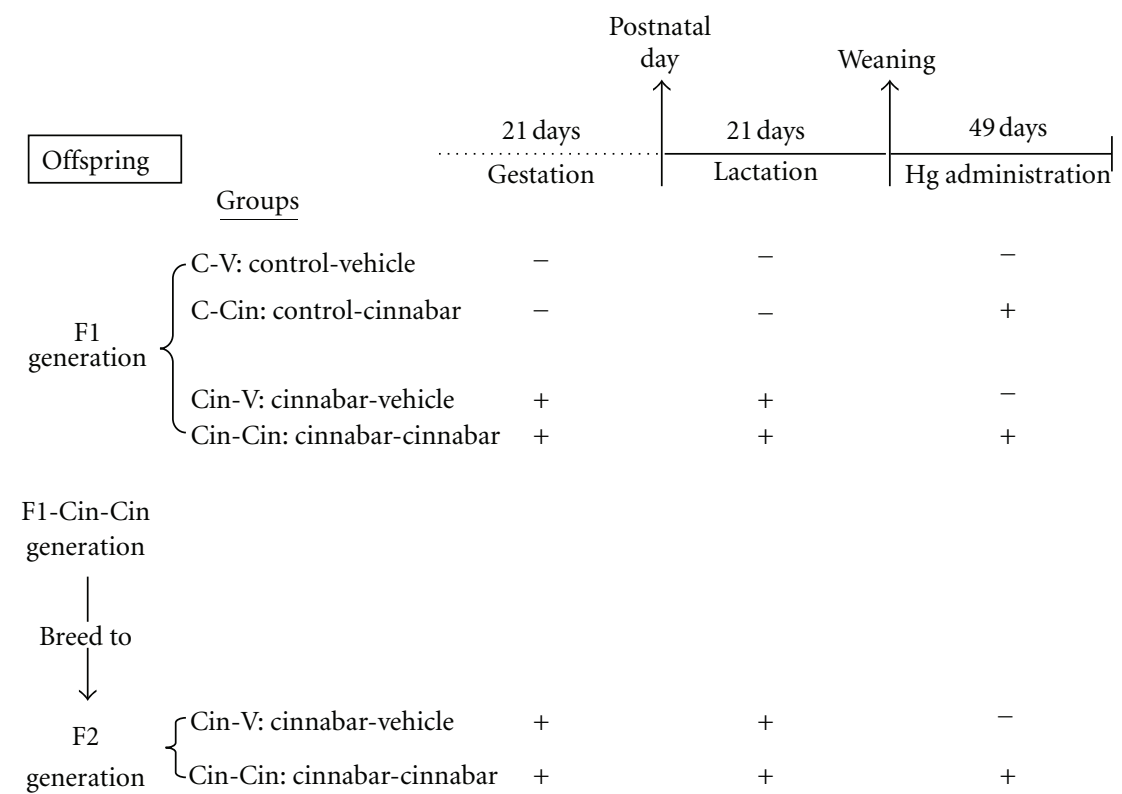

FIGURE 1: Schedule of oral administration of cinnabar $(10 \mathrm{mg} / \mathrm{kg} /$ day $)$ to offsprings during maternal gestation, weaning, or after weaning.

stored at $-80^{\circ} \mathrm{C}$ until use. These tissues were analysis of $\mathrm{Na}^{+} / \mathrm{K}^{+}$-ATPase activities (cerebral cortex, cerebellar cortex and brainstem), nitric oxide levels of whole blood, and mercury content (whole blood, cerebral cortex, cerebellar cortex, and brainstem).

2.2. Determination of Mercury Contents. To determine the $\mathrm{Hg}$ concentrations, various tissues $(300 \mathrm{mg}$ of whole blood, cerebral cortex, cerebellar cortex and brainstem or offspring newborn mice) or cinnabar sample $(100 \mathrm{mg})$ were placed in a $15 \mathrm{~mL}$ polyethylene tube, and $0.4 \mathrm{~mL}$ of a $3: 1$ mixture of hydrochloric acid (35\%) and nitric acid (70\%) was added. The tubes were capped and allowed to stand overnight at 50 degree oven. After cooling, suitable dilution buffer $(0.3 \%$ nitric acid and $0.1 \%$ Triton X-100 in distilled water) was added to the digested material, and the total mercury content was determined by Inductively Coupled Plasma Mass Spectrometry (ICP-MS). The detection limit for mercury was $\sim 0.1 \mathrm{ppb}(\mu \mathrm{g} / \mathrm{L})$. The cinnabar sample used in this study was composed: $809.3 \mathrm{mg} / \mathrm{g}$ of mercury, $1.03 \mathrm{mg} / \mathrm{g}$ of sodium, $0.12 \mathrm{mg} / \mathrm{g}$ of magnesium, $0.06 \mathrm{mg} / \mathrm{g}$ of aluminum, $4.37 \mathrm{mg} / \mathrm{g}$ of potassium, $0.73 \mathrm{mg} / \mathrm{g}$ of calcium, $1.05 \mathrm{mg} / \mathrm{g}$ of barium, $1.05 \mathrm{mg} / \mathrm{g}$ of Chromium, $1.62 \mathrm{mg} / \mathrm{g}$ of iron, $0.05 \mathrm{mg} / \mathrm{g}$ of zinc, $0.04 \mathrm{mg} / \mathrm{g}$ of selenium, $0.01 \mathrm{mg} / \mathrm{g}$ of lead, $0.01 \mathrm{mg} / \mathrm{g}$ of copper, and $0.02 \mathrm{mg} / \mathrm{g}$ nickel.

2.3. Spontaneous Locomotor Activity. The mice were orally administered cinnabar by gavage or distilled water once every day for 7 consecutive weeks, and the effects on the spontaneous locomotor activity were measured at end of 7 weeks treatment. In the spontaneous locomotor activity tests, the experiments were performed during the day (9:0018:00). When the drugs were administered by consecutive oral route, the mice were individually placed in an open field. A large colorless rectangular box with a metallic grid floor was used ( $70 \mathrm{~cm}$ wide, $90 \mathrm{~cm}$ long and $60 \mathrm{~cm}$ high). The photobeam activity monitors (Tru Scan coulbourn instruments) were used as well as real-time for detecting track-type plots. Overall pulses were recorded in an electromechanical counter as a gross measure of activity. Typical application of $\mathrm{X}-\mathrm{Y}$ activity recording (floor plane activity) sensory ring drops over the cage and rests on ring support. Movement was detected by $16 \times 16$ infrared photobeam detectors and transducers set $1.5 \mathrm{~cm}$ above the floor of the apparatus and measured by a PC. Finally, the number of squares crossed and the plots of tracking were counted during a period of $30 \mathrm{~min}$ for all experiments, and quantification of data was by TruScan 99 software.

2.4. Prolongation of Pentobarbital-Induced Sleeping Time. In order to investigate the neurotoxic effect of cinnabarinduced sleep disorder in offspring mice, prolongation of pentobarbital-induced sleeping time was performed $[13,32]$. Briefly, the prolongation of sleeping time was induced by an intraperitoneal injection of pentobarbital $(50 \mathrm{mg} / \mathrm{kg})$ and recorded the sleeping time from anesthesia to awakening at end of 7 weeks in the mice with or without cinnabar administration.

2.5. Motor Equilibrium Performance. The motor equilibrium performance on a rotating rod is a more complex motor skill task, which requires both fine motor coordination and precise postural control and is an useful marker for monitoring mercurial compounds-induced neurotoxicity [21, 33, 34]. The effect of cinnabar on motor coordination in the separate groups of the mice was tested using an accelerating rotating rod treadmill (Ugo Basile; Stoelting Co., Chicago, IL). The rotating rod was set in motion at a constant speed $(60 \mathrm{rpm})$, 
and the mice were placed into individual sections of rotating rod. Each time an animal fell, it was noted whether the fall had occurred when it sat still or when it walked. The effect of drug administration on motor equilibrium performance was measured once every week.

2.6. Recording of Auditory Brainstem Responses (ABRs). The mice were administered with distilled water or cinnabar once every day for 7 consecutive weeks. ABRs were monitored after administration with cinnabar at end of 7-week treatment. The ABR recording was based on that described by Huang et al. [21, 34]. Briefly, experimental mice were deep anesthetized with an intraperitoneal injection of pentobarbital ( $50 \mathrm{mg} / \mathrm{kg}$ body weight), keeping the body temperature by an electric blanket and recording the brainstem evoked response in a sound attenuated room. Subcutaneous needle electrodes with active electrodes placed in the vertex and ipsilateral retro-auricular region and a ground electrode on the neck of the animal recorded the click-evoked ABR by an auditory evoked potential system (Nicolet, Spirit, Madison, WI, USA). Mice were presented with a stimulus intensity series, which was initiated at $110 \mathrm{~dB}$ sound pressure level (SPL) and reached a minimum of $-5 \mathrm{~dB}$ SPL. The intensity of the stimulus was varied in a $5 \mathrm{~dB}$ stepwise decrement. Click stimuli were calibrated with a calibrated B \& K precision sound level meter (duration $100 \mu \mathrm{s}$, stimulation rate $57.7 / \mathrm{s}$, and frequency from 0 to $150 \mathrm{~Hz}$ ). ABR threshold was defined as the lowest intensity capable of eliciting replicable and detectable waveforms. The absolute wave and interwave latencies of $\mathrm{ABR}$ waveforms were also recorded at a $105 \mathrm{~dB}$ SPL signal intensity. ABR was evoked by clicks in this study because the click-elicited ABR is a simplified and effective electrophysiological test to examine the hearing loss induced by mercurial compounds, and its hearing thresholds would correlate with the enzyme activities of the brainstem of the experimental mice.

2.7. Measurement of Nitric Oxide $\left(\mathrm{NO}_{x}\right)$ Detection. The quantitative nitric oxide $\left(\mathrm{NO}_{x}\right)$ assay was based on that described by Huang et al. [21, 34] and Young et al. [12]. Briefly, the whole blood samples were collected to eppendorf from an eyehole vessel of the experimental animals after light anesthesia by an intraperitoneal injection of pentobarbital $(50 \mathrm{mg} / \mathrm{kg})$. To avoid total protein denatured incompletely, we added $95 \%$ ethanol into the eppendorf at $4^{\circ} \mathrm{C}$ overnight (12-16 hrs). Next day, all samples were centrifuged at $4^{\circ} \mathrm{C}$ for $20 \mathrm{~min}$ at $12000 \times \mathrm{g}$. The supernatants of these samples were collected and assayed by the $\mathrm{NO}$ /ozone chemiluminescence (NO Analyzer 280A SIEVERS) for quantitative $\mathrm{NO}_{x}$ levels, which measured the oxidation products $\left(\mathrm{NO}_{2}-\right.$ and $\left.\mathrm{NO}_{3}-\right)$ of $\mathrm{NO}$ using a reaction vessel containing a reducing system (0.1 M vanadium chloride, Aldrich Co., Germany). Detection of $\mathrm{NO}_{x}$ is then completed by its reaction with ozone, which leads to the emission of red light $\left(\mathrm{NO}+\mathrm{O}_{3} \rightarrow \mathrm{NO}_{2}{ }^{*}\right.$ $\left.+\mathrm{O}_{2} ; \mathrm{NO}_{2}{ }^{*} \rightarrow \mathrm{NO}_{2}+h v\right)$. Standard curves were made prior to concentration $(1,5,10,15$, and $20 \mu \mathrm{M} \mathrm{NO})$, which were prepared using freshly prepared solutions of $\mathrm{NaNO}_{2}$ in distilled water.
2.8. $\mathrm{Na}^{+} / \mathrm{K}^{+}$-ATPase Activity of Brain Tissue. The brain tissues (cerebral cortex, cerebellar cortex and brainstem) of the vehicle control and cinnabar treated mice were acquired and analyzed for $\mathrm{Na}^{+} / \mathrm{K}^{+}$-ATPase activity after 7 weeks subsequent cinnabar fed. Membrane $\mathrm{Na}^{+} / \mathrm{K}^{+}$-ATPase activities were assayed as described previously (Huang et al. $[21,34])$. The method allowed for quantification of two distinct $\mathrm{Na}^{+} / \mathrm{K}^{+}$-ATPase and $\mathrm{Mg}^{2+}$-ATPase activities in the same sample. The enzymatic activities were measured in triplicate in covered 96 -well microliter plates at $37 \pm 0.5^{\circ} \mathrm{C}$ on a shaker. Thirty microliters of assay buffer $(118 \mathrm{mM}$ $\mathrm{NaCl}, 1.67 \mathrm{mM} \mathrm{KCl}, 1.2 \mathrm{mM} \mathrm{MgCl}_{2}, 12.3 \mathrm{mM} \mathrm{NaHCO}$, $11 \mathrm{mM}$ glucose, $0.5 \mathrm{mM}$ EGTA, PH: 7.4) containing $2 \mu \mathrm{g}$ of membrane protein was added to each well. The $\mathrm{Na}^{+} / \mathrm{K}^{+}$ATPase activity was determined by subtracting the ouabain $(1.25 \mathrm{mM})$ insensitive $\mathrm{Mg}^{2+}$-ATPase activity from the overall $\mathrm{Na}^{+} / \mathrm{K}^{+} / \mathrm{Mg}^{2+}$-ATPase and the assay was started with the addition of $10 \mu \mathrm{l}$ of ATP (final concentration $5 \mathrm{mM}$ ) making the final reaction volume of $100 \mu \mathrm{l}$. The reaction was terminated after preincubation at $37 \pm 0.5^{\circ} \mathrm{C}$ by the addition of $200 \mu \mathrm{l}$ of malachite green (MG) plus ammonium molybdate (AM) $(3: 1)$. The inorganic phosphate $(\mathrm{Pi})$ released from the substrate ATP was colorimetrically assayed by a microplate ELISA reader (Dynatech MR7000, Ashford, Middesex, UK) at $630 \mathrm{~nm}$. The absorbance values obtained were converted to activity values by linear regression using a standard curve of sodium monobasic phosphate that included in the assay procedure. The specific ATPase activities were expressed as Pi $\mu$ mole (micromoles inorganic phosphate) released per mg protein per hr. Values reported represent mean $\pm \mathrm{SE}$ of at least three separate experiments.

2.9. Statistical Analysis. The results in the text are given as mean \pm standard errors (SE). The significance of difference was evaluated by the Student's $t$-test. When more than one group was compared with one control, significance was evaluated according to one-way analysis of variance (ANOVA) was used for analysis, and the Duncans's post hoc test was applied to identify group differences. The $P$ value less than 0.05 was considered to be significant.

\section{Results}

3.1. Changes in Litter Number and Levels of Mercury in Maternal Whole Blood and Offspring at Postnatal Day (PND) 1 following Cinnabar Exposure. As shown in Figure 2, the mean of the number of offspring per litter whose dam exposed to low dose of cinnabar $(10 \mathrm{mg} / \mathrm{kg})$ was significantly decreased (12.2 \pm 0.6 and $10.1 \pm 0.6$ in F1 and F2 generation, resp.) compared with F1-control group (14.4 \pm 0.4$)$. The body weight of the offspring in groups exposed to low dose of cinnabar $(10 \mathrm{mg} / \mathrm{kg})$ (F1 and F2 generations) at PND 1 was also significantly lower $(1.44 \pm 0.02$ and $1.45 \pm 0.02 \mathrm{~g}$, resp. $)$ than in age-matched control $(1.63 \pm 0.02 \mathrm{~g})$. Moreover, the $\mathrm{Hg}$ content of the cinnabar-exposed maternal (dams) whole blood was $8.1 \pm 1.2$ and $6.3 \pm 0.4 \mathrm{ppb}$ for F0 and F1 dams, respectively, which was significantly higher than that of the control $(2.0 \pm 0.3 \mathrm{ppb})$ (Table 1$)$. Likewise, the Hg content 


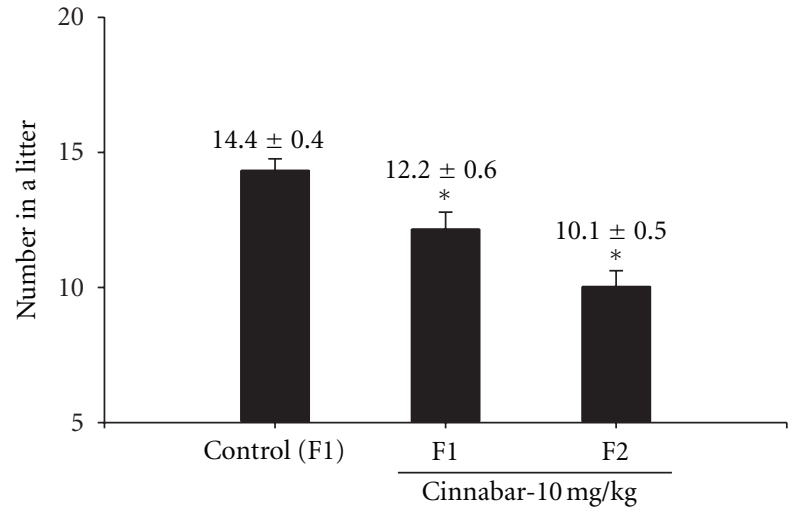

FIGURE 2: Decrease of litter number induced by cinnabar. Cinnabar $(10 \mathrm{mg} / \mathrm{kg} /$ day) was treated with the dams by oral gavage during gestation period. Numbers of newborn pups were recorded at postnatal day 1 (PND 1) as described in the section of Materials and Methods. All data are presented as mean \pm S.E. $(n=12-15 /$ group $)$. ${ }^{*} P<0.05$ as compared with $\mathrm{F} 1$ control vehicle (F1-C-V) group.

was markedly higher in the cinnabar-exposed pups at PND 1 than in age-matched control (Table 1).

3.2. Mercury Accumulation in the Brain Tissues of Offspring Mice following Exposure to Cinnabar. To investigate whether the mercury within cinnabar could be absorbed by the GI tract, pass through the blood-brain-barrier (BBB), and accumulate in the brain, we detected the $\mathrm{Hg}$ content of the cerebral cortex, cerebellar cortex, and brainstem by ICP-MS. As shown in Table 2, the Hg contents in the cerebral cortex, cerebellar cortex, and brainstem were slightly increased in F1- and F2-Cin-V groups ( $P<0.05$ as compared with F1$\mathrm{C}-\mathrm{V}$ group (age-matched control)) and markedly increased in F1-C-Cin group, F1- and F2-Cin-Cin groups, but only the brainstem of F1-C-Cin group significantly accumulated $\mathrm{Hg}$ than F1- and F2-Cin-Cin groups. Moreover, the $\mathrm{Hg}$ levels of liver and kidney, especially in the kidney, were also significantly accumulated in F1- and $\mathrm{F} 2-\mathrm{Cin}-\mathrm{V}$ groups ( $P<0.05$ as compared with $\mathrm{F} 1-\mathrm{C}-\mathrm{V}$ group), and there were gradually and significantly increased $\mathrm{Hg}$ levels in $\mathrm{F} 1-$ and F2-Cin-Cin groups more than those in F1-C-Cin group ( ${ }^{\#} P<0.05$ as compared with $\mathrm{F} 1-\mathrm{C}-\mathrm{Cin}$ group).

\subsection{Changes in Body Weight, Neurobehavioral \\ Abnormalities, and Auditory Dysfunction Induced by Low Dose of Cinnabar in Offspring Mice}

3.3.1. Altered Body Weight. As shown in Figure 3, the growth of mice in both F1- and F2-Cin-V groups (as assessed by the gain in body weight) was significantly decreased compared with F1-C-V group (decreased by $12.9 \pm 1.6 \%$ in F1-Cin-V; $8.3 \pm 2.2 \%$ in $\mathrm{F} 2-\mathrm{Cin}-\mathrm{V}$, resp.). However, further decrease in the continuing exposure to cinnabar for 7 consecutive weeks (decreased by $12.8 \pm 2.2 \%$ in F1-Cin-Cin group; $10.9 \pm 1.4 \%$ in F2-Cin-Cin group) was not revealed.
3.3.2. Abnormal Spontaneous Locomotor Activities, Motor Equilibrium Performance, and Prolonged PentobarbitalInduced Sleeping Time. To investigate neurotoxicity induced by exposure to low dose of cinnabar in offspring, we examined spontaneous locomotor activities (a useful method for detecting the central function of neurotransmission or motor dysfunction on mercury-induced neurotoxicity [21] in cinnabar-treated offspring. As shown in Figures 4(a) and 4(b), F1-C-Cin group was revealed to be hypoactive in terms of its quantitative ambulatory distances and stereotype-1 episodes following exposure to cinnabar $\left({ }^{*} P<0.05\right.$ as compared with F1-C-V group). However, those parameters were significantly increased (hyperactive) in F1-, F2-Cin$\mathrm{V}$ and F1-, F2-Cin-Cin groups $\left({ }^{*} P<0.05\right.$ as compared with F1-C-V group; ${ }^{\#} P<0.05$ as compared with F1-C-Cin group), and only F1-Cin-Cin group showed more severely effects than F1-Cin-V group $\left({ }^{\&} P<0.05\right)$. In the parameter of jump (Figure 4(c)), a marked decrease was observed in F1-C-Cin group $\left({ }^{*} P<0.05\right.$ as compared with $\mathrm{F} 1-\mathrm{C}-\mathrm{V}$ group). F1- and F2-Cin-V groups were found to show slight declines in this parameter, which were higher as in F1- and F2-Cin-Cin groups ( ${ }^{\&} P<0.05$ as compared with $\mathrm{F} 1$ - or F2-Cin- $\mathrm{V}$ group, resp.). Meanwhile, the motor equilibrium performance test of F1-C-Cin and F1- and F2-Cin-Cin groups showed remarkably decreased retention times on the rotating rod $\left({ }^{*} P<0.05\right.$ as compared with $\mathrm{F} 1-\mathrm{C}-\mathrm{V}$ group), with the decrease being especially severe in F2-Cin-Cin group $\left({ }^{\circledR} P<0.05\right.$ as compared with $\mathrm{F} 2-\mathrm{Cin}-\mathrm{V}$; ${ }^{\#} P<0.05$ as compared with F1-C-Cin group) (Figure 4(d)).

In addition, the administration of cinnabar for 7 consecutive weeks after weaning (F1-C-Cin group) caused a definite prolongation of pentobarbital-induced sleeping time, which was $33.4 \pm 2.4 \mathrm{~min}$ compared with $24.4 \pm 1.0 \mathrm{~min}$ in F1$\mathrm{C}-\mathrm{V}$ group $\left({ }^{*} P<0.05\right.$, Figure 5$)$. However, no significant increase in the pentobarbital-induced sleeping time was observed after exposure to cinnabar during the perinatal and weaning stages (F1- and F2-Cin-C groups). A remarkable prolongation of sleeping time by pentobarbital-induced was, however, revealed in F1- and F2-Cin-Cin groups by continuing exposure to cinnabar for further 7 consecutive weeks $\left({ }^{*} P<0.05\right.$ as compared with F1-C-V group; ${ }^{*} P<0.05$ as compared with F1- or F2-Cin-V group, respectively), and this was even more significant than that in F1-C-Cin group $\left({ }^{\#} P<0.05\right)$.

3.3.3. Auditory Dysfunction. To further understand whether the low dose of cinnabar $(10 \mathrm{mg} / \mathrm{kg})$ induced ototoxicity in offspring, the hearing thresholds were determined using the ABR test. As shown in Figure 6, the means of hearing threshold was significantly elevated in F1-C-Cin group $(11.67 \pm 2.99 \mathrm{~dB}$ SPL in F1-C-Cin group as compared with $5.00 \pm 1.60 \mathrm{~dB}$ SPL in F1-C-V group; $* P<0.05)$. Both F1and $\mathrm{F} 2-\mathrm{Cin}-\mathrm{V}$ groups also had hearing thresholds (17.25 \pm 2.52 and $30.00 \pm 3.27 \mathrm{~dB}$ SPL respectively, as compared with the F1-C-V group; ${ }^{*} P<0.05$ ), and this effect was found to be more severe following a further 7 consecutive weeks of exposure $(23.80 \pm 2.02$ and $50.63 \pm 6.44 \mathrm{~dB}$ SPL in the F1Cin-Cin and F2-Cin-Cin groups, respectively; ${ }^{*} P<0.05$ as compared with the F1-C-V group; ${ }^{\circledR} P<0.05$ as compared 
TABLE 1: Hg contents of dam's blood and offspring (whole body at PND 1) mice after administration with low dose of cinnabar.

\begin{tabular}{lccc}
\hline \multicolumn{1}{c}{ Dam's (whole blood) } & Offspring (whole body) & Generation \\
\hline F0 (Distilled water) & $2.0 \pm 0.3$ & $1.8 \pm 0.1$ & F1-control \\
F0 (Cinnabar-10mg/kg/day) & $8.1 \pm 1.2^{*}$ & $6.3 \pm 0.5^{*}$ & F1-Cinnabar \\
F1 (Cinnabar-10mg/kg/day)* & $6.3 \pm 0.4$ & $5.2 \pm 0.2^{*}$ & F2-Cinnabar \\
\hline
\end{tabular}

At postnatal day 1 (PND 1), the offspring mice (pups) were randomly selected as representatives of their respective litters (four or five per litter). Hg content was expressed as $\mathrm{ng} / \mathrm{g}$ of wet-weight and presented as mean $\pm \mathrm{SE}$.

$* P<0.05$ as compared with control group.

TABLE 2: Hg contents of whole blood and brain tissues of offspring mice treated with cinnabar.

\begin{tabular}{lccccc}
\hline Group & Cerebral cortex & Cerebellar cortex & Brainstem & Liver & Kidney \\
\hline F1-C-V & $3.15 \pm 0.17$ & $4.35 \pm 0.13$ & $7.26 \pm 0.31$ & $10.06 \pm 1.40$ & $29.40 \pm 1.15$ \\
F1-C-Cin & $17.56 \pm 2.10^{*}$ & $22.75 \pm 1.66^{*}$ & $50.06 \pm 4.66^{*}$ & $30.55 \pm 4.96^{*}$ & $99.53 \pm 6.04^{*}$ \\
F1-Cin-V & $8.53 \pm 0.08^{*}$ & $8.59 \pm 0.48^{*}$ & $13.29 \pm 0.20^{*}$ & $14.36 \pm 0.98^{*}$ & $43.59 \pm 2.95^{*}$ \\
F1-Cin-Cin & $19.02 \pm 2.27^{*, \&}$ & $34.62 \pm 0.51^{*, \&, \#}$ & $28.88 \pm 2.68^{*, \&, \#}$ & $52.44 \pm 4.58^{*, \&, \#}$ & $182.63 \pm 39.40^{*, \&, \#}$ \\
F2-Cin-V & $5.73 \pm 1.25^{*}$ & $10.36 \pm 3.72^{*}$ & $8.23 \pm 1.02$ & $19.12 \pm 3.46^{*}$ & $74.14 \pm 10.97^{*}$ \\
F2-Cin-Cin & $13.01 \pm 0.97^{*, \&}$ & $26.26 \pm 2.63^{*, \&}$ & $27.56 \pm 3.84^{*, \&, \#}$ & $68.80 \pm 5.70^{*, \&, \#}$ & $369.68 \pm 14.61^{*, \&, \#}$ \\
\hline
\end{tabular}

Data of $\mathrm{Hg}$ content in various tissues were expressed as ng/g of wet-weight and presented as mean \pm SE ( $n=12-15 /$ group).

${ }^{*} P<0.05$ as compared with F1-C-V group; ${ }^{\circledR} P<0.05$ as compared with $\mathrm{F} 1-$ or $\mathrm{F} 2-\mathrm{Cin}-\mathrm{V}$ group; ${ }^{\#} P<0.05$ as compared with F1-C-Cin group, respectively.

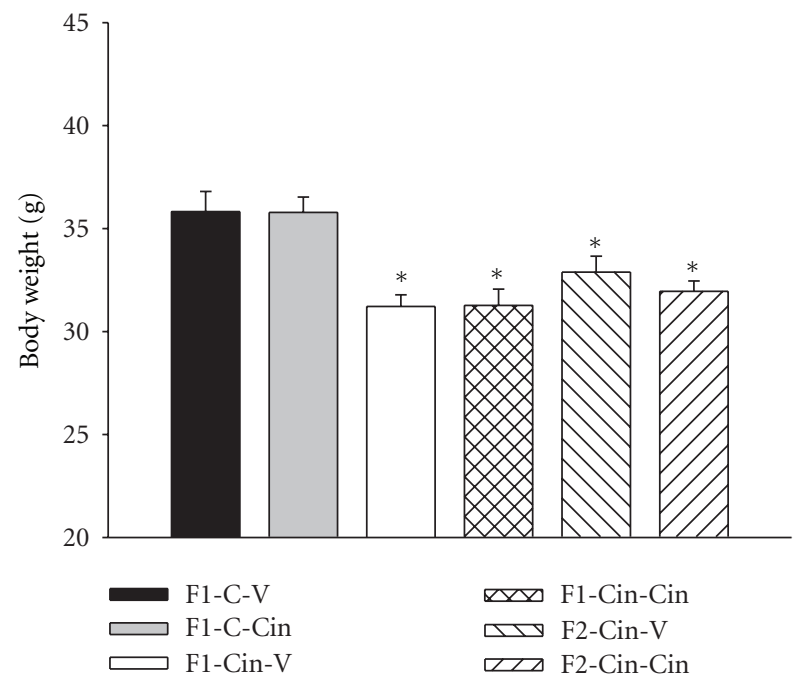

Figure 3: Effects of cinnabar on body weight gain of offspring mice. After weaning, the offspring mice were randomly selected as representatives of their respective litters ( $n=12-15$ /group), and body weights were determined in various experimental groups after 49 consecutively treated days as described in Figure 1. Data are presented as mean $\pm \mathrm{SE}$. ${ }^{*} P<0.05$ as compared with $\mathrm{F} 1-\mathrm{C}-\mathrm{V}$ group.

with F1- or F2-Cin-V group, respectively; ${ }^{\#} P<0.05$ as compared with the F1-C-Cin group). Moreover, the extent of the elevation of the hearing thresholds was greater in F2-CinCin group than in F1-Cin-Cin group $(P<0.05$; Figure 6(a)).

The absolute wave and interwave latencies of ABR were also observed to be significantly delayed by low dose of cinnabar exposed (Figures 6(b) and 6(c)). The mean values of the absolute latency of wave I and III were unaffected as compared with the age-matched control group (F1-C-V group), but those of wave $\mathrm{V}$ were increased in all exposed groups $\left({ }^{*} P<0.05\right.$ as compared with F1-C-V group; ${ }^{\&} P<$ 0.05 as compared with F1- or F2-Cin-V group, respectively), especially in F2-Cin-Cin group $\left({ }^{\#} P<0.05\right.$ as compared with F1-C-Cin group). In addition, the interwave latencies of I-V and III-V, but not that of I-III, were significantly increased in all exposed groups. In particularly, the III-V interwave of F2-Cin-Cin group was more markedly increased than that in F1-Cin-Cin group $(P<0.05$; Figure 6(c)).

3.4. Exposure of Offspring Mice to Low Dose of Cinnabar Caused the Alteration of Nitric Oxide $\left(\mathrm{NO}_{x}\right)$ Levels in the Whole Blood and $\mathrm{Na}^{+} / \mathrm{K}^{+}$-ATPase Activities in the Brain Tissues. To examine whether changes in nitric oxide levels and $\mathrm{Na}^{+} / \mathrm{K}^{+}$-ATPase activities were involved in low dose of cinnabar-induced neurotoxicity in offspring mice, we first analyzed the nitric oxide $\left(\mathrm{NO}_{x}\right.$ : nitrate plus nitrite) levels of whole blood by the NO/ozone chemiluminescence. As shown in Figure 7, $\mathrm{NO}_{x}$ levels in the whole blood were significantly increased in F1- and F2-Cin-V groups (28.8 \pm 1.5 and $27.4 \pm 1.6 \mu \mathrm{M}$, respectively; $\left.{ }^{*} P<0.05\right)$ as compared with F1-C-V group $(19.9 \pm 0.8 \mu \mathrm{M})$ and even more markedly increased in F1-C-Cin and F1-Cin-Cin groups $(22.4 \pm 0.9 \mu \mathrm{M}$ and $37.5 \pm 0.6 \mu \mathrm{M}$, resp.; $\left.{ }^{*} P<0.05\right)$, particularly in F1-CinCin group $\left({ }^{\&} P<0.05\right.$ as compared with $\mathrm{F} 1-\mathrm{Cin}-\mathrm{V}$ group; ${ }^{\#} P<0.05$ as compared with F1-C-Cin group). Conversely, there was a decrease the $\mathrm{NO}_{x}$ level in F2-Cin-Cin group, which was more intensively acted as compared with F1-CinCin group $(16.4 \pm 1.3 \mathrm{mM}$ versus $19.9 \pm 0.8 \mathrm{mM} ; P<0.05$; Figure 7).

Next, we detected $\mathrm{Na}^{+} / \mathrm{K}^{+}$-ATPase enzyme activities of the brain regions in offspring mice exposed to low dose of cinnabar for 7 consecutive weeks. As shown in Figure 8, $\mathrm{Na}^{+} / \mathrm{K}^{+}$-ATPase activities in F1-C-Cin group were increased 


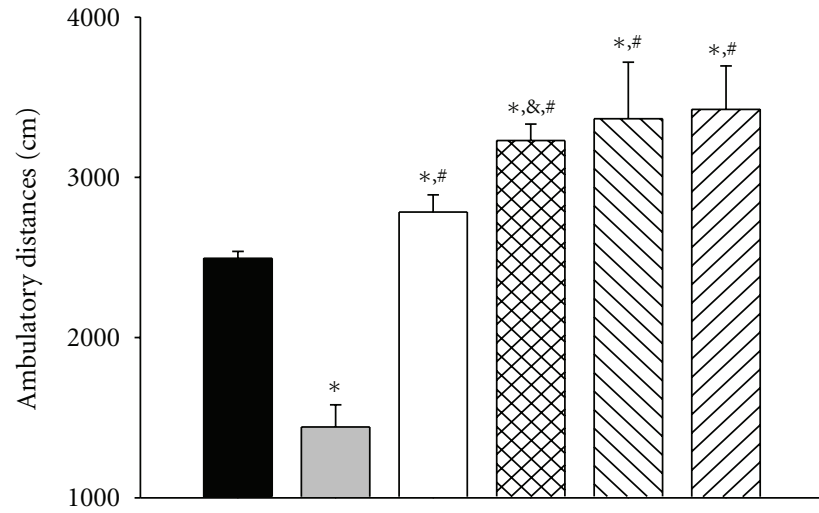

(a)

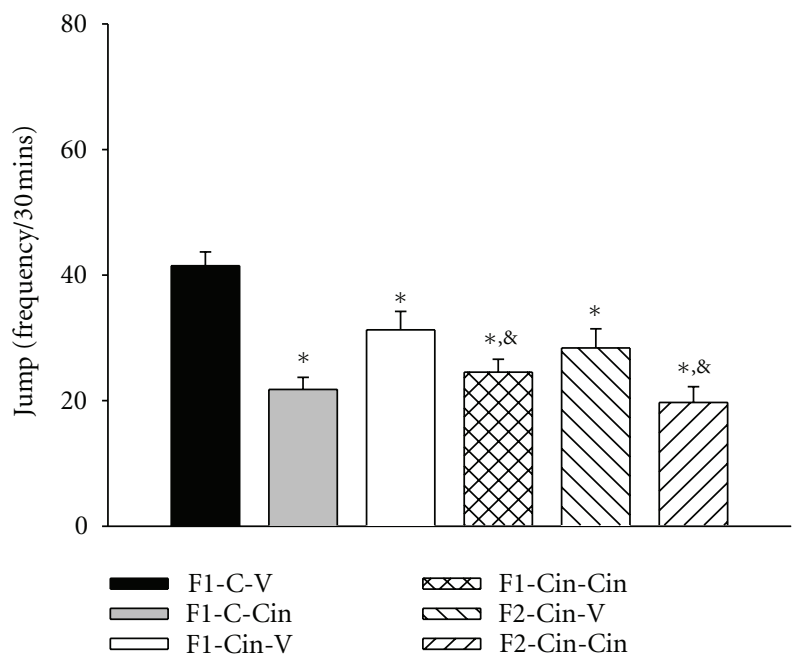

(c)

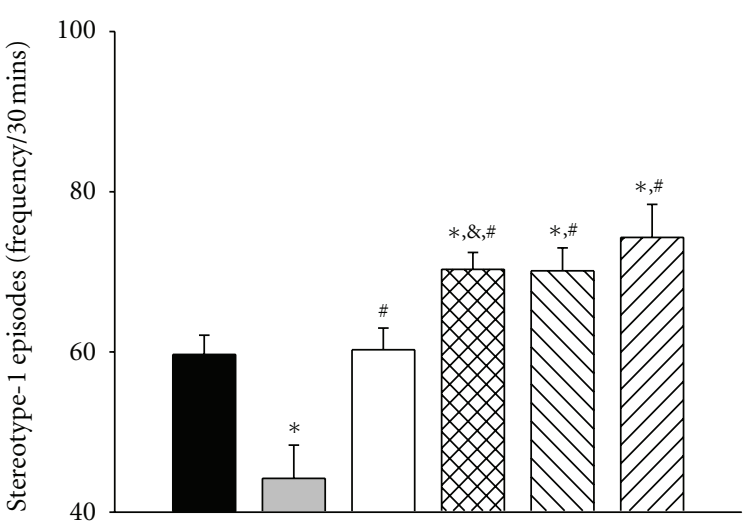

(b)

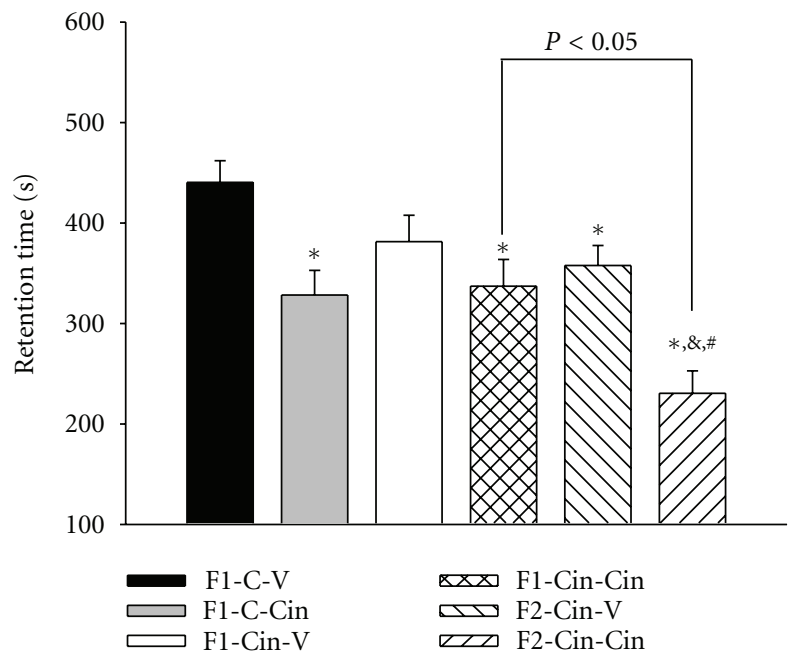

(d)

FIGURE 4: Changes in locomotor activities and motor equilibrium performance of offspring mice treated with cinnabar. Experimental mice were treated with cinnabar $(10 \mathrm{mg} / \mathrm{kg} /$ day) or distilled water as described in Figure 1 . Spontaneous locomotor activities (ambulatory distance (a), stereotypy-1 episodes (b) and Jump (c)) and motor equilibrium performance (retention times on rotating rod, $60 \mathrm{rpm}$ (d)) of all groups were recorded and analyzed as described of Materials and Methods. Data are presented as mean \pm SE $(n=12-15 /$ group $)$. ${ }^{*} P<0.05$ as compared with F1-C-V group; ${ }^{\circledR} P<0.05$ as compared with F1- or F2-Cin-V group; ${ }^{\#} P<0.05$ as compared with F1-C-Cin group, respectively.

in the cerebral and cerebellar cortex $(* P<0.05$ as compared with F1-C-V group). In F1- and F2-Cin-V groups, $\mathrm{Na}^{+} / \mathrm{K}^{+}-$ ATPase activities were significantly enhanced in the cerebral and cerebellar cortex of F1-Cin-V group, but unaffected that in F2-Cin-V group. In F1- and F2-Cin-Cin groups, $\mathrm{Na}^{+} / \mathrm{K}^{+}$-ATPase activities were altered more intensively with an increase in the cerebral cortex of both groups and a decrease in the cerebellar cortex of the F1-Cin-Cin group and, most notably, an increase in the cerebellar cortex of the F2-Cin-Cin group $\left({ }^{\circledR} P<0.05\right.$ as compared with F1or F2-Cin-V group, resp.; ${ }^{\#} P<0.05$ as compared with F1$\mathrm{C}$-Cin group). In the brainstem (the main organ of central auditory system), $\mathrm{Na}^{+} / \mathrm{K}^{+}$-ATPase activities were increased in F1-C-Cin group and also changed in the mice exposed during the perinatal and weaning stages (decreased in F1Cin-V group; increased in F2-Cin-V group). In F1- and F2-Cin-Cin groups, there was a gradual but clear increase in $\mathrm{Na}^{+} / \mathrm{K}^{+}$-ATPase activities of the brainstem compared with F1-C-Cin group. Furthermore, the changes of $\mathrm{Na}^{+} / \mathrm{K}^{+}-$ ATPase activities of the brain in F2-Cin-Cin group were more significant than those observed in F1-Cin-Cin group $(P<$ 0.05; Figure 8).

\section{Discussion}

Cinnabar has been used as a TCM for the management of various diseases for more than 2000 years, especially as a tranquilizer for infants or adults, and is still used in Asia countries $[3,5,8]$. The reputed insolubility of cinnabar, or its counterpart $\mathrm{HgS}$, has led to the assumption or disregard that it is not significantly absorbed from the G-I tract following oral administration, and thus it is generally considered to have a low toxicity in vivo. However, many studies have 


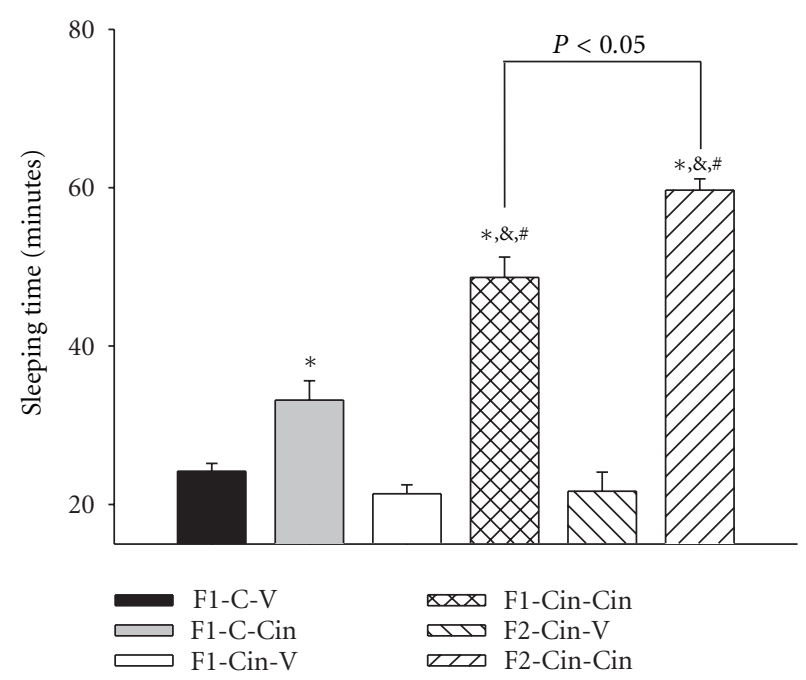

Figure 5: Prolongation of pentobarbital-induced sleeping time by cinnabar in offspring mice. Offspring mice were administered with distilled water or cinnabar $(10 \mathrm{mg} / \mathrm{kg} /$ day, oral application by gavage) as described in Figure 1. Sleeping time was measured at the end of 49 days after weaning as described in Materials and Methods. Data are presented as mean \pm S.E. $(n=12-15$ /group $) .{ }^{*} P<0.05$ as compared with F1-C-V group; ${ }^{\#} P<0.05$ as compared with F1or F2-Cin-V group; ${ }^{*} P<0.05$ as compared with F1-C-Cin group, respectively.

found that mercury content of cinnabar, or $\mathrm{HgS}$, can still be significantly absorbed from G-I tract, and transported and accumulated to various tissues after oral administration at the high dose or sufficient levels in the experimental animals to induce neurotoxicity $[10-12,22]$. Subsequently, it has been revealed that oral administration of cinnabar $(0.01 \mathrm{~g} / \mathrm{kg} /$ day $)$ for 11 consecutive weeks produced neurobehavioral abnormalities [13]. In addition, many studies have documented that mercury could be transferred to the fetus through the placenta and to newborn offspring through maternal milk, which caused the high level mercury accumulation in brain and the severe deficit of neurobehavioral and learning disability in offspring $[1,31,33,35]$. Based on these findings, we considered that expectant women, infants, or children might encounter overdoses of cinnabar through long-term therapy with TCM leading to mercury poison. Therefore, it was necessary to clarify whether a low dose (an actual clinical dose of 5-25 mg/kg/day) of cinnabar could be significantly absorbed from G-I tract and exert its toxic effects by interfering with the integrity and functional performance of the central nervous system (CNS) following exposure during the perinatal and/or developmental periods. To investigate the extent of $\mathrm{Hg}$ absorbed from G-I tract and the subsequent neurobiological effects of low dose of cinnabar, we first investigated the effects of cinnabar $(10 \mathrm{mg} / \mathrm{kg} /$ day $)$ in offspring exposed to cinnabar during differential developmental stages. Our results showed that: (1) exposure to low dose of cinnabar from weaning for 7 consecutive weeks (F1-C-Cin group) induced neurotoxic responses (Figures 4, 5 , and 6) and (2) exposure to cinnabar during the perinatal and weaning stages, and then continued exposure for a further 7 consecutive weeks after weaning (F1- and F2-CinCin groups) caused more significant abnormalities of spontaneous locomotor activities (hyperactivities), disruption of motor equilibrium performance, prolonged pentobarbitalinduced sleeping time, and dysfunction of the auditory system (elevated hearing thresholds and delayed absolute latency of wave $\mathrm{V}$ and interwave latencies of $\mathrm{I}-\mathrm{V}, \mathrm{III}-\mathrm{V}$ ), particularly in F2-Cin-Cin group more severe than F1-CinCin group, which were accompanied by significant $\mathrm{Hg}$ accumulation in the brain regains. The cerebrum and cerebellum offered several unique advantages as the controlled motor coordination. If those regions were injuries by toxic insults, it would induce neurobehavioral abnormalities, such as hyperactivities in the ambulatory distances and stereotype1 episodes of the spontaneous locomotor activities and the disruption of rotarod performance $[21,36]$. Due to this, our results not only agree with previous findings that the exposure to low dose mercurial compounds $(\mathrm{MeHgCl}$ and/or mercuric chloride $\left(\mathrm{HgCl}_{2}\right)$ ) for 3 to 7 consecutive weeks caused hyperactivity and disruption of motor equilibrium performance and auditory function [21,34], but also verify that offspring were much more severe and susceptible to mercurial compounds-induced neurotoxicological injuries during the perinatal and/or developmental periods exposed.

Furthermore, results of this study also found that offspring treated with low dose of cinnabar (F1- and F2Cin-Cin groups) exhibited more abnormal prolonged wave $(\mathrm{V})$ and interwave (I-V and III-V) latencies in the ABR, indicating an abnormality at a late phase of the ABR at the higher center (Figure 6(b) and Figure 6(c)), which was in accordance with the clinical effects of mercury upon the brainstem auditory pathway of children or the occupational workers in the mercury contaminated area with a discernible prolongation of interwave latency I-III and III-V and the higher levels of $\mathrm{Hg}$ accumulation [18, 19, 21, 22]. These phenomena might be due to the fact that $\mathrm{I}-\mathrm{V}$ and III-V interwave latencies relate to the central auditory pathway of the brainstem, and cinnabar (as well as $\mathrm{MeHg}$ ) could be absorbed and passed through the BBB, accumulate in the brainstem, and cause central neurotoxicity. Moreover, our results also showed that offspring that were exposed to low dose of cinnabar only during the perinatal and weaning stages (in F1- and F2-Cin-V groups) still revealed irreversible neurotoxicological damage (Figures 4 and 6) despite the finding that their brain $\mathrm{Hg}$ levels (about $30 \mathrm{ppb}$ ) were lower than, or equal to, levels measured in brain tissue from victims of mercury-contaminated areas or experimental animals [37-39]. These findings indicate that exposure to low dose of cinnabar can still be absorbed $\mathrm{Hg}$ from the G-I tract, transported to brain regions where they can cause dysfunction of the neurobehavioral abnormalities and auditory system following a continuous long-term exposure regime of more than 7 consecutive weeks. In addition, exposure to cinnabar during perinatal and weaning stages can cause irreversible impairments. It was also observed through this work that the ABR system may provide a sensitive and powerful tool for detecting subclinical central hearing impairment induced by cinnabar. 


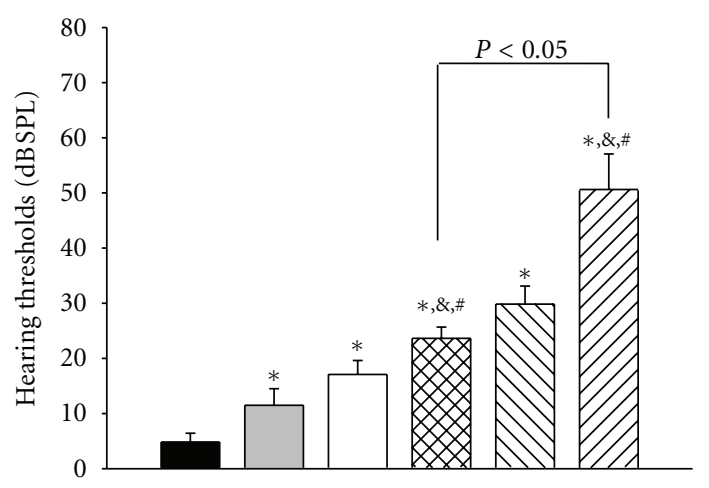

(a)

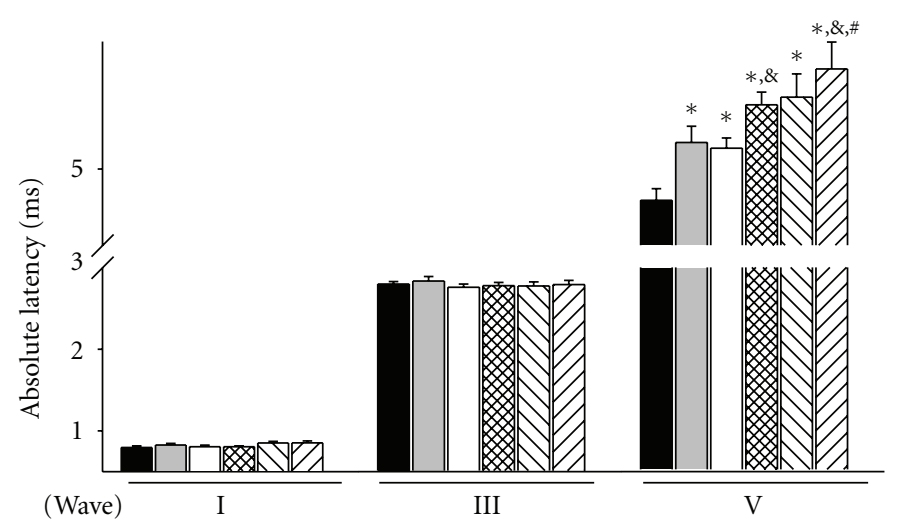

(b)

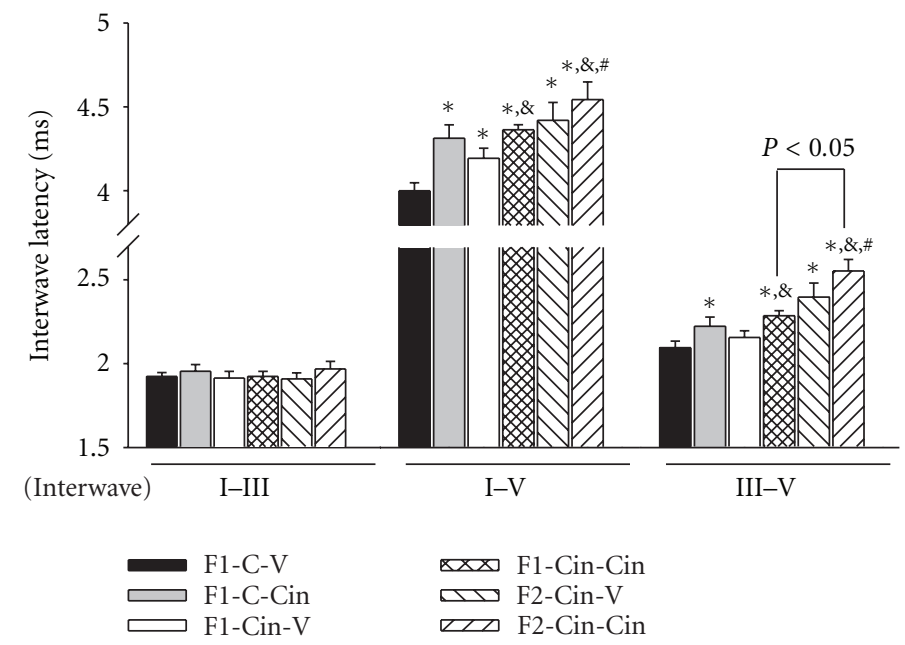

(c)

FIGURE 6: Chronological change of hearing thresholds and the absolute and the interwave latencies of ABRs waveforms in offspring mice treated with cinnabar. Offspring mice were orally gavaged with either cinnabar $(10 \mathrm{mg} / \mathrm{kg} /$ day $)$ or distilled water as described in Figure 1 . The hearing thresholds (a), absolute wave (I, III, and V) (b), and the interwave latencies (I-III, I-V, and III-V) (c) of ABRs waveforms were recorded as described in Materials and Methods. Data are presented as mean $\pm \mathrm{SE}(n=12-15 /$ group $) .{ }^{*} P<0.05$ as compared with F1-C-V group; ${ }^{\circledR} P<0.05$ as compared with F1- or F2-Cin-V group; ${ }^{\#} P<0.05$ as compared with F1-C-Cin group, respectively.

Arito et al. [32] showed that short-term exposure of adult rat to $\mathrm{MeHg}$ (total doses of 10 and $30 \mathrm{mg} / \mathrm{kg}$ ) led to a marked sleep disorder (an increase in both slow-wave sleep and paradoxical sleep in the dark phase, as well as long-lasting sleep-waking changes) and that was accompanied by high levels of $\mathrm{Hg}$ in the brain. In this study, the results showed that offspring exposed to low dose of cinnabar $(10 \mathrm{mg} / \mathrm{kg} /$ day $)$ for 7 consecutive weeks beginning after weaning (in F1C-Cin group) had a significantly prolonged pentobarbitalinduced sleeping time, and this was even more severe in all experimental stage exposed to low dose of cinnabar, particularly in F2-Cin-Cin group more than F1-Cin-Cin group $(P<0.05$; Figure 5$)$. These changes were accompanied by notable $\mathrm{Hg}$ accumulation in the brain (Table 2). Thus, these results suggest that offspring exposed to low dose of cinnabar during the prenatal and weaning stages and followed by continued exposure for further 7 consecutive weeks can suffer disturbances of the sleep-waking pattern (a severe sleep disorder).

The membrane bound $\mathrm{Na}^{+} / \mathrm{K}^{+}$-ATPase is essential for the generation or maintenance of basic cellular $\mathrm{Na}^{+}$and $\mathrm{K}^{+}$ ion homeostasis and the functioning of specialized tissues, such as the nervous system. The inhibition of this enzyme could result in membrane depolarization, leading to the suppression of neuronal and excitatory transmission [40, 41]. It has been reported that $\mathrm{Na}^{+} / \mathrm{K}^{+}$-ATPase activities are very sensitive totoxic agents, which are the significant alteration (increase or inhibition) during mercurial compounds-induced neurological injuries in vivo or in vitro especially in brain regions and the cochlear lateral wall, which is accompanying with the significant increase in hearing loss $[10,11,21-23,42-44]$. Furthermore, a recent study has indicated that low dose and long-term exposure to $\mathrm{MeHgCl}$ and $\mathrm{HgCl}_{2}$ in offspring during the prenatal, 


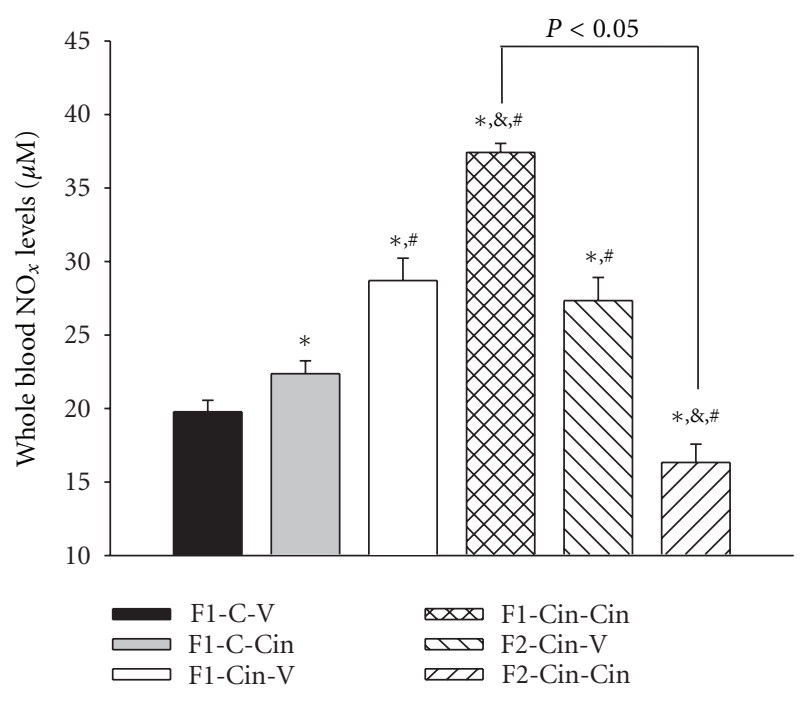

Figure 7: Nitric oxide $\left(\mathrm{NO}_{x}\right)$ levels of the whole blood of offspring mice treated with cinnabar. Experimental mice were orally gavaged with cinnabar $(10 \mathrm{mg} / \mathrm{kg} /$ day $)$ as described in Figure 1 . Whole blood samples were acquired, de-proteinized, and $\mathrm{NO}_{x}$ levels were determined as described in Materials and Methods. All data are presented as mean $\pm \mathrm{SE}\left(n=12-15\right.$ /group). ${ }^{*} P<0.05$ as compared with compared with F1-C-V group; ${ }^{8} P<0.05$ as compared with F1or F2-Cin-V group; ${ }^{\#} P<0.05$ as compared with F1-C-Cin group, respectively.

neonatal, and/or postnatal periods cause neurotoxicological effects, which is accompanied with the marked increase $\mathrm{Na}^{+} / \mathrm{K}^{+}$-ATPase activities in the cerebral cortex, cerebellar cortex, and brainstem [34]. Nevertheless, an important role of $\mathrm{Na}^{+} / \mathrm{K}^{+}$-ATPase activities in the neurotoxic effects induced by long-term exposure to low dose of cinnabar in differential offspring remained unclear. Moreover, nitric oxide $\left(\mathrm{NO}_{x}\right)$ is also an important signaling molecule that not only mediates several physiological functions, including the regulation of neurotransmission, but also regulates many pathological processes $[45,46] . \mathrm{NO}_{x}$ plays a crucial factor in the regulation of $\mathrm{Na}^{+} / \mathrm{K}^{+}$-ATPase activities in brain, and less or excess of $\mathrm{NO}_{x}$ production can result in neurotoxicity $[47,48]$. Acute exposure to high-dose of toxic metals has been indicated to be capable of inhibiting $\mathrm{NO}_{x}$ levels in vivo and in vitro $[22,49,50]$. Recently, accumulated evidence has reported that the chronic exposure to toxic insults induces significant alteration of $\mathrm{Na}^{+} / \mathrm{K}^{+}$-ATPase activities in brain accompanied with the whole blood and/or brain $\mathrm{NO}_{x}$ changes $[12,51,52]$ and increased or decreased the whole blood $\mathrm{NO}_{x}$ levels, which closely correlates with the exposure to low dose of mercurial compounds-induced neurotoxicity, has been revealed $[13,21,34]$. Here, our results demonstrated that $\mathrm{Na}^{+} / \mathrm{K}^{+}$-ATPase activities in the cerebral cortex, cerebellar cortex, and brainstem of offspring were significantly increased after the administration of a low dose of cinnabar for 7 consecutive weeks (the F1-CCin group), which were related to the increase of $\mathrm{NO}_{x}$ levels in the whole blood. Furthermore, offspring that were only exposed during the perinatal and weaning stages

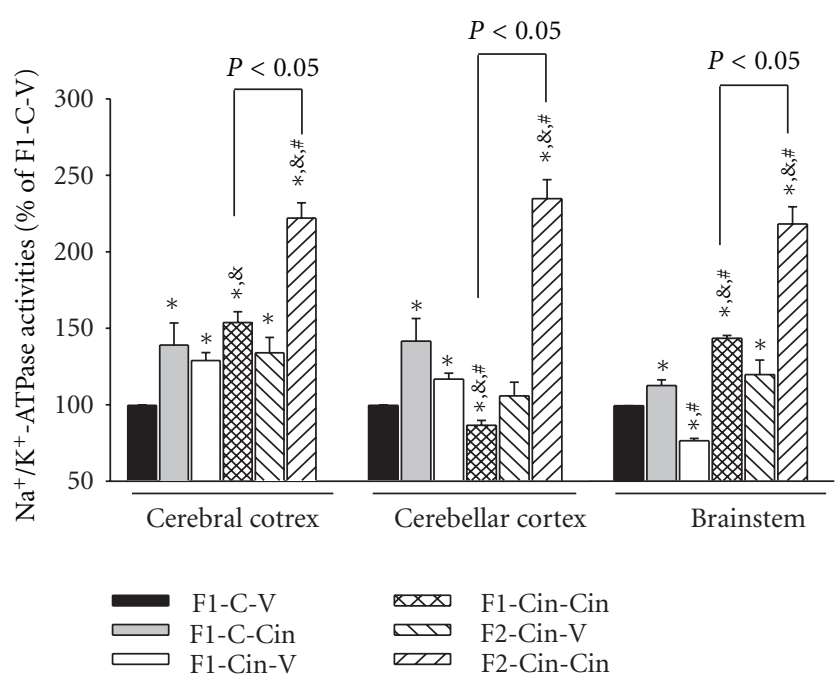

Figure 8: Alteration of $\mathrm{Na}^{+} / \mathrm{K}^{+}$-ATPase activities in the brain tissues of offspring mice treated with cinnabar. Experimental mice were orally administrated with distilled water or cinnabar $\left(10 \mathrm{mg} / \mathrm{kg} /\right.$ day) as described in Figure $1 . \mathrm{Na}^{+} / \mathrm{K}^{+}$-ATPase activities of the cerebral cortex, cerebellar cortex and brainstem were determined as described in the section of Materials and Methods. All data are presented as mean \pm S.E. $(n=12-15$ /group). $* P<0.05$ as compared with F1-C-V group; ${ }^{\circledR} P<0.05$ as compared with F1or F2-Cin-V group; ${ }^{\#} P<0.05$ as compared with F1-C-Cin group, respectively.

(F1- and F2-Cin-V groups) had markedly altered $\mathrm{Na}^{+} / \mathrm{K}^{+}$ATPase activities in all of the three brain regions tested and elevated $\mathrm{NO}_{x}$ levels in the whole blood, which more severely changed following further exposure to cinnabar for further 7 consecutive weeks (alterant effect: F2-Cin-Cin > F1-CinCin group; $P<0.05$; Figures 7 and 8 ). These findings implicate that cinnabar can alter $\mathrm{Na}^{+} / \mathrm{K}^{+}$-ATPase activities of the brain and $\mathrm{NO}_{x}$ levels of the whole blood, which maybe responsible for inducing the dysfunctions of nervous (abnormalities of locomotor activities and motor equilibrium performance) and central auditory system (elevation of hearing thresholds, and delay of absolute latency and interwave latency). In addition, recent studies have suggested that changes in $\mathrm{Na}^{+} / \mathrm{K}^{+}$-ATPase activities and/or $\mathrm{NO}_{x}$ levels could be the useful biochemical markers for chemicalinduced neuronal injuries or subclinical disease, especially in mercuric compounds-induced neurotoxicity $[21,53,54]$. Based on these suggestions and our findings, we suggest that $\mathrm{Na}^{+} / \mathrm{K}^{+}$-ATPase activities and $\mathrm{NO}_{x}$ levels appear to serve as an important and useful biochemical marker of lower dose of cinnabar-induced neurotoxicity.

\section{Conclusion}

In conclusion, our results provide a toxicological basis for cinnabar-induced neurotoxic and ototoxic effects in offspring mice, which may be extrapolated to adults and children exposed to therapeutic dosage in TCM. Changes in $\mathrm{NO}_{x}$ levels and $\mathrm{Na}^{+} / \mathrm{K}^{+}$-ATPase activities appear to 
be the underlying mechanism of the toxicological effects of cinnabar, which may supply an important and useful biomarker in offspring exposure to low dose and long-term mercuric compounds-induced neurotoxicity.

\section{Funding}

This study was supported by research grants from Committee on Chinese Pharmacy, Department of Health, Executive Yuan (CCMP92-RD-044, CCMP100-RD-046) and also supported in part by Taiwan Department of Health Clinical Trial and Research Center of Excellence (DOH101-TD-B111-004).

\section{References}

[1] J. R. O'Kusky, B. E. Boyes, and E. G. McGeer, "Methylmercuryinduced movement and postural disorders in developing rat: regional analysis of brain catecholamines and indoleamines," Brain Research, vol. 439, no. 1-2, pp. 138-146, 1988.

[2] M. Uchino, Y. Tanaka, Y. Ando et al., "Neurologic features of chronic minamata disease (organic mercury poisoning) and incidence of complications with aging," Journal of Environmental Science and Health-Part B, vol. 30, no. 5, pp. 699-715, 1995.

[3] B. Tie, W. Qi, and G. Chen, "Determination of soluble mercury contents in Chinese traditional patent medicines for children," Zhongguo Zhong Yao Za Zhi, vol. 15, no. 10, pp. 602639, 1990.

[4] E. O. Espinoza, M. J. Mann, and B. Bleasdell, "Arsenic and mercury in traditional Chinese herbal balls," The New England Journal of Medicine, vol. 333, no. 12, pp. 803-804, 1995.

[5] A. D. Hardy, H. H. Sutherland, R. Vaishnav, and M. A. Worthing, "A report on the composition of mercurials used in traditional medicines in Oman," Journal of Ethnopharmacology, vol. 49, no. 1, pp. 17-22, 1995.

[6] Pharmacoeia Comittee, Pharmacopoeia of China, Chemical Industry Press, Beijing, China, 2005.

[7] E. Ernst and J. Thompson Coon, "Heavy metals in traditional Chinese medicines: a systematic review," Clinical Pharmacology and Therapeutics, vol. 70, no. 6, pp. 497-504, 2001.

[8] E. Kang-Yum and S. H. Oransky, "Chinese patent medicine as a potential source of mercury poisoning," Veterinary and Human Toxicology, vol. 34, no. 3, pp. 235-238, 1992.

[9] C. C. Yen, S. H. Liu, W. K. Chen, R. H. Lin, and S. Y. LinShiau, "Tissue distribution of different mercurial compounds analyzed by the improved FI-CVAAS," Journal of Analytical Toxicology, vol. 26, no. 5, pp. 286-295, 2002.

[10] J. J. Chuu, S. H. Liu, and S. Y. Lin-Shiau, "Effects of methyl mercury, mercuric sulfide and cinnabar on active avoidance responses, $\mathrm{Na}^{+} / \mathrm{K}^{+}$-ATPase activities and tissue mercury contents in rats," Proceedings of the National Science Council, Republic of China. Part B, vol. 25, no. 2, pp. 128-136, 2001.

[11] J. J. Chuu, S. H. Liu, and S. Y. Lin-Shiau, "Differential neurotoxic effects of methylmercury and mercuric sulfide in rats," Toxicology Letters, vol. 169, no. 2, pp. 109-120, 2007.

[12] Y. H. Young, J. J. Chuu, S. H. Liu, and S. Y. Lin-Shiau, "Neurotoxic mechanism of cinnabar and mercuric sulfide on the vestibulo-ocular reflex system of guinea pigs," Toxicological Sciences, vol. 67, no. 2, pp. 256-263, 2002.
[13] C. F. Huang, S. H. Liu, and S. Y. Lin-Shiau, "Neurotoxicological effects of cinnabar (a Chinese mineral medicine, $\mathrm{HgS}$ ) in mice," Toxicology and Applied Pharmacology, vol. 224, no. 2, pp. 192-201, 2007.

[14] A. H. Liang, Y. J. Xu, and M. F. Shang, "Analysis of adverse effects of cinnabar," Zhongguo Zhong Yao Za Zhi, vol. 30, no. 23, pp. 1809-1811, 2005.

[15] S. A. Counter, M. Vahter, G. Laurell, L. H. Buchanan, F. Ortega, and S. Skerfving, "High lead exposure and auditory sensory-neural function in Andean children," Environmental Health Perspectives, vol. 105, no. 5, pp. 522-526, 1997.

[16] M. F. Wu, J. R. Ison, J. R. Wecker, and L. W. Lapham, "Cutaneous and auditory function in rats following methyl mercury poisoning," Toxicology and Applied Pharmacology, vol. 79, no. 3, pp. 377-388, 1985.

[17] S. A. Counter, L. H. Buchanan, G. Laurell, and F. Ortega, "Blood mercury and auditory neuro-sensory responses in children and adults in the nambija gold mining area of ecuador," NeuroToxicology, vol. 19, no. 2, pp. 185-196, 1998.

[18] K. Murata, P. Weihe, S. Araki, E. Budtz-Jorgensen, and P. Grandjean, "Evoked potentials in Faroese children prenatally exposed to methylmercury," Neurotoxicology and Teratology, vol. 21, no. 4, pp. 471-472, 1999.

[19] K. Murata, P. Weihe, E. Budtz-Jorgensen, P. J. Jorgensen, and P. Grandjean, "Delayed brainstem auditory evoked potential latencies in 14-year-old children exposed to methylmercury," The Journal of Pediatrics, vol. 144, no. 2, pp. 177-183, 2004.

[20] F. E. Musiek and D. P. Hanlon, "Neuroaudiological effects in a case of fatal dimethylmercury poisoning," Ear and Hearing, vol. 20, no. 3, pp. 271-275, 1999.

[21] C. F. Huang, C. J. Hsu, S. H. Liu, and S. Y. Lin-Shiau, "Neurotoxicological mechanism of methylmercury induced by low-dose and long-term exposure in mice: oxidative stress and down-regulated $\mathrm{Na}^{+} / \mathrm{K}^{+}$-ATPase involved," Toxicology Letters, vol. 176, no. 3, pp. 188-197, 2008.

[22] J. J. Chuu, C. J. Hsu, and S. Y. Lin-Shiau, "Abnormal auditory brainstem responses for mice treated with mercurial compounds: involvement of excessive nitric oxide," Toxicology, vol. 162, no. 1, pp. 11-22, 2001.

[23] I. Hajek, J. Teisinger, and E. Sykova, "The effect of opioids and of naloxone on $\mathrm{Na}^{+}, \mathrm{K}^{+}$-adenosine triphosphatase activity in frog spinal cord membrane fractions," Neuroscience Letters, vol. 59, no. 3, pp. 291-295, 1985.

[24] B. M. Anner and M. Moosmayer, "Mercury inhibits NaK-ATPase primarily at the cytoplasmic side," The American Journal of Physiology, vol. 262, no. 5, pp. F843-F848, 1992.

[25] L. Ji, A. Chauhan, W. T. Brown, and V. Chauhan, "Increased activities of $\mathrm{Na}^{+} / \mathrm{K}^{+}$-ATPase and $\mathrm{Ca}^{2+} / \mathrm{Mg}^{2+}$-ATPase in the frontal cortex and cerebellum of autistic individuals," Life Sciences, vol. 85, no. 23-26, pp. 788-793, 2009.

[26] L. V. Karpova, E. R. Bulygina, and A. A. Boldyrev, "Different neuronal $\mathrm{Na}^{+} / \mathrm{K}^{+}$-ATPase isoforms are involved in diverse signaling pathways," Cell Biochemistry and Function, vol. 28, no. 2, pp. 135-141, 2010.

[27] Z. Xie and T. Cai, " $\mathrm{Na}^{+}-\mathrm{K}^{+}$-ATPase-mediated signal transduction: from protein interaction to cellular function," Molecular Interventions, vol. 3, no. 3, pp. 157-168, 2003.

[28] S. P. Yu, " $\mathrm{Na}^{+}, \mathrm{K}^{+}$-ATPase: the new face of an old player in pathogenesis and apoptotic/hybrid cell death," Biochemical Pharmacology, vol. 66, no. 8, pp. 1601-1609, 2003.

[29] S. Bhattacharya, S. Bose, B. Mukhopadhyay et al., "Specific binding of inorganic mercury to $\mathrm{Na}^{+}-\mathrm{K}^{+}$-ATPase in rat liver plasma membrane and signal transduction," BioMetals, vol. 10, no. 3, pp. 157-162, 1997. 
[30] X. Wang and J. D. Horisberger, "Mercury binding site on $\mathrm{Na}^{+} / \mathrm{K}^{+}$-ATPase: a cysteine in the first transmembrane segment," Molecular Pharmacology, vol. 50, no. 3, pp. 687-691, 1996.

[31] J. L. Franco, A. Teixeira, F. C. Meotti et al., "Cerebellar thiol status and motor deficit after lactational exposure to methylmercury," Environmental Research, vol. 102, no. 1, pp. 22-28, 2006.

[32] H. Arito, N. Hara, and S. Torii, "Effect of methylmercury chloride on sleep-waking rhythms in rats," Toxicology, vol. 28, no. 4, pp. 335-345, 1983.

[33] M. Sakamoto, A. Kakita, K. Wakabayashi, H. Takahashi, A. Nakano, and H. Akagi, "Evaluation of changes in methylmercury accumulation in the developing rat brain and its effects: a study with consecutive and moderate dose exposure throughout gestation and lactation periods," Brain Research, vol. 949, no. 1-2, pp. 51-59, 2002.

[34] C. F. Huang, S. H. Liu, C. J. Hsu, and S. Y. Lin-Shiau, "Neurotoxicological effects of low-dose methylmercury and mercuric chloride in developing offspring mice," Toxicology Letters, vol. 201, no. 3, pp. 196-204, 2011.

[35] S. Goulet, F. Y. Doré, and M. E. Mirault, "Neurobehavioral changes in mice chronically exposed to methylmercury during fetal and early postnatal development," Neurotoxicology and Teratology, vol. 25, no. 3, pp. 335-347, 2003.

[36] K. L. Marquis, N. C. Paquette, R. P. Gussio, and J. E. Moreton, "Comparative electroencephalographic and behavioral effects of phenylcyclidine, (+)-SKF-10,047 and MK-801 in rats," Journal of Pharmacology and Experimental Therapeutics, vol. 251, no. 3, pp. 1104-1112, 1989.

[37] P. Grandjean, P. Weihe, R. F. White et al., "Cognitive deficit in 7-year-old children with prenatal exposure to methylmercury," Neurotoxicology and Teratology, vol. 19, no. 6, pp. 417428, 1997.

[38] P. Li, X. Feng, and G. Qiu, "Methylmercury exposure and health effects from rice and fish consumption: a review," International Journal of Environmental Research and Public Health, vol. 7, no. 6, pp. 2666-2691, 2010.

[39] T. Takeuchi and K. Eto, The Pathology of Minamata Disease, Kyushu University Press, Hakozaki, Japan, 1999.

[40] M. Balestrino, J. Young, and P. Aitken, "Block of $\left(\mathrm{Na}^{+}, \mathrm{K}^{+}\right)$ATPase with ouabain induces spreading depressionlike depolarization in hippocampal slices," Brain Research, vol. 838, no. 1-2, pp. 37-44, 1999.

[41] A. T. S. Wyse, C. S. Bavaresco, E. A. Reis et al., "Training in inhibitory avoidance causes a reduction of $\mathrm{Na}^{+}, \mathrm{K}^{+}$-ATPase activity in rat hippocampus," Physiology and Behavior, vol. 80, no. 4, pp. 475-479, 2004.

[42] J. Albrecht and W. Hilgier, "Similarities of the in vivo and in vitro effects of mercuric chloride on $\left[{ }^{3} \mathrm{H}\right]$ ouabain binding and potassium activation of $\mathrm{Na}^{+} / \mathrm{K}^{+}$-ATPase in isolated rat cerebral microvessels," Toxicology Letters, vol. 70, no. 3, pp. 331-336, 1994.

[43] G. Szumanska, R. Gadamski, and J. Albrecht, "Changes of the $\mathrm{Na} / \mathrm{K}$ ATPase activity in the cerebral cortical microvessels of rat after single intraperitoneal administration of mercuric chloride: histochemical demonstration with light and electron microscopy," Acta Neuropathologica, vol. 86, no. 1, pp. 65-70, 1993.

[44] P. W. Cheng, S. H. Liu, C. J. Hsu, and S. Y. Lin-Shiau, "Correlation of increased activities of $\mathrm{Na}^{+}, \mathrm{K}^{+}$-ATPase and $\mathrm{Ca}^{2+}$-ATPase with the reversal of cisplatin ototoxicity induced by D-methionine in guinea pigs," Hearing Research, vol. 205, no. 1-2, pp. 102-109, 2005.
[45] S. Moncada and E. A. Higgs, "Endogenous nitric oxide: physiology, pathology and clinical relevance," European Journal of Clinical Investigation, vol. 21, no. 4, pp. 361-374, 1991.

[46] A. G. Estévez and J. Jordán, "Nitric oxide and superoxide, a deadly cocktail," Annals of the New York Academy of Sciences, vol. 962, pp. 207-211, 2002.

[47] N. F. Avrova, K. I. Shestak, I. O. Zakharova, T. V. Sokolova, and V. G. Leont'ev, "The difference in the effect of glutamate and $\mathrm{NO}$ synthase inhibitor on free calcium concentration and $\mathrm{Na}^{+}, \mathrm{K}^{+}$-ATPase activity in synaptosomes from various brain regions," Neurochemical Research, vol. 24, no. 9, pp. 11011106, 1999.

[48] A. Conti, M. Miscusi, S. Cardali et al., "Nitric oxide in the injured spinal cord: synthases cross-talk, oxidative stress and inflammation," Brain Research Reviews, vol. 54, no. 1, pp. 205218, 2007.

[49] C. K. Mittal, W. B. Harrell, and C. S. Mehta, "Interaction of heavy metal toxicants with brain constitutive nitric oxide synthase," Molecular and Cellular Biochemistry, vol. 149-150, pp. 263-265, 1995.

[50] H. Yanagisawa, M. Nodera, M. Sato, K. Moridaira, G. Sato, and O. Wada, "Decreased expression of brain nitric oxide synthase in macula densa cells and glomerular epithelial cells of rats with mercury chloride-induced acute renal failure," Toxicology and Applied Pharmacology, vol. 184, no. 3, pp. 165-171, 2002.

[51] C. F. Huang, R. S. Yang, S. H. Liu, P. C. Hsieh, and S. Y. Lin-Shiau, "Evidence for improved neuropharmacological efficacy and decreased neurotoxicity in mice with traditional processing of Rhizoma Arisaematis," The American Journal of Chinese Medicine, vol. 39, no. 5, pp. 981-998, 2011.

[52] H. Zha, Z. Cheng, J. Chen et al., "The toxicological effects in brain of mice following exposure to cerium chloride," Biological Trace Element Research, vol. 144, no. 1-3, pp. 872884, 2011.

[53] G. Nicolini, S. Balzan, R. Colzani, M. Scarlattini, M. C. Taddei, and G. Iervasi, "Erythrocyte $\mathrm{Na}^{+} / \mathrm{K}^{+}$-ATPase is increased in subjects with subclinical hypothyroidism," Clinical Endocrinology, vol. 60, no. 6, pp. 705-710, 2004.

[54] D. Pałecz, R. Komuński, and T. Gabryelak, " $\mathrm{Na}^{+} \mathrm{K}^{+}$-ATPase activity as a biomarker of toxaphene toxicity in Unio tumidus," Toxicology in Vitro, vol. 19, no. 5, pp. 707-712, 2005. 

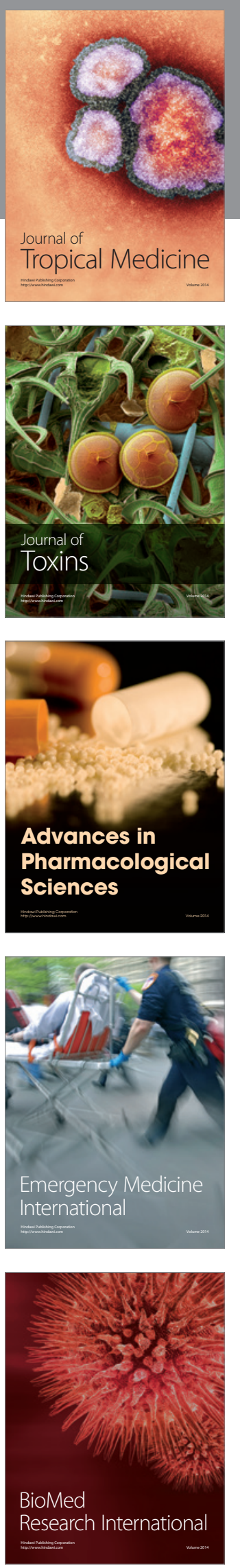
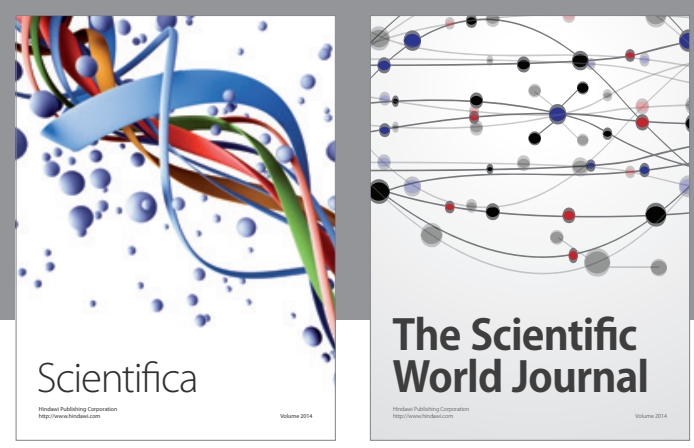

The Scientific World Journal
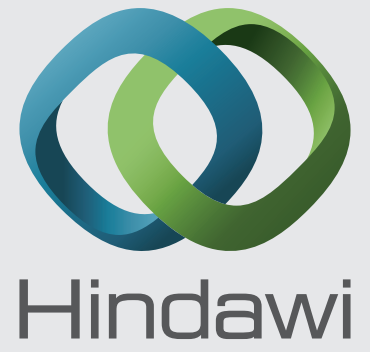

Submit your manuscripts at

http://www.hindawi.com
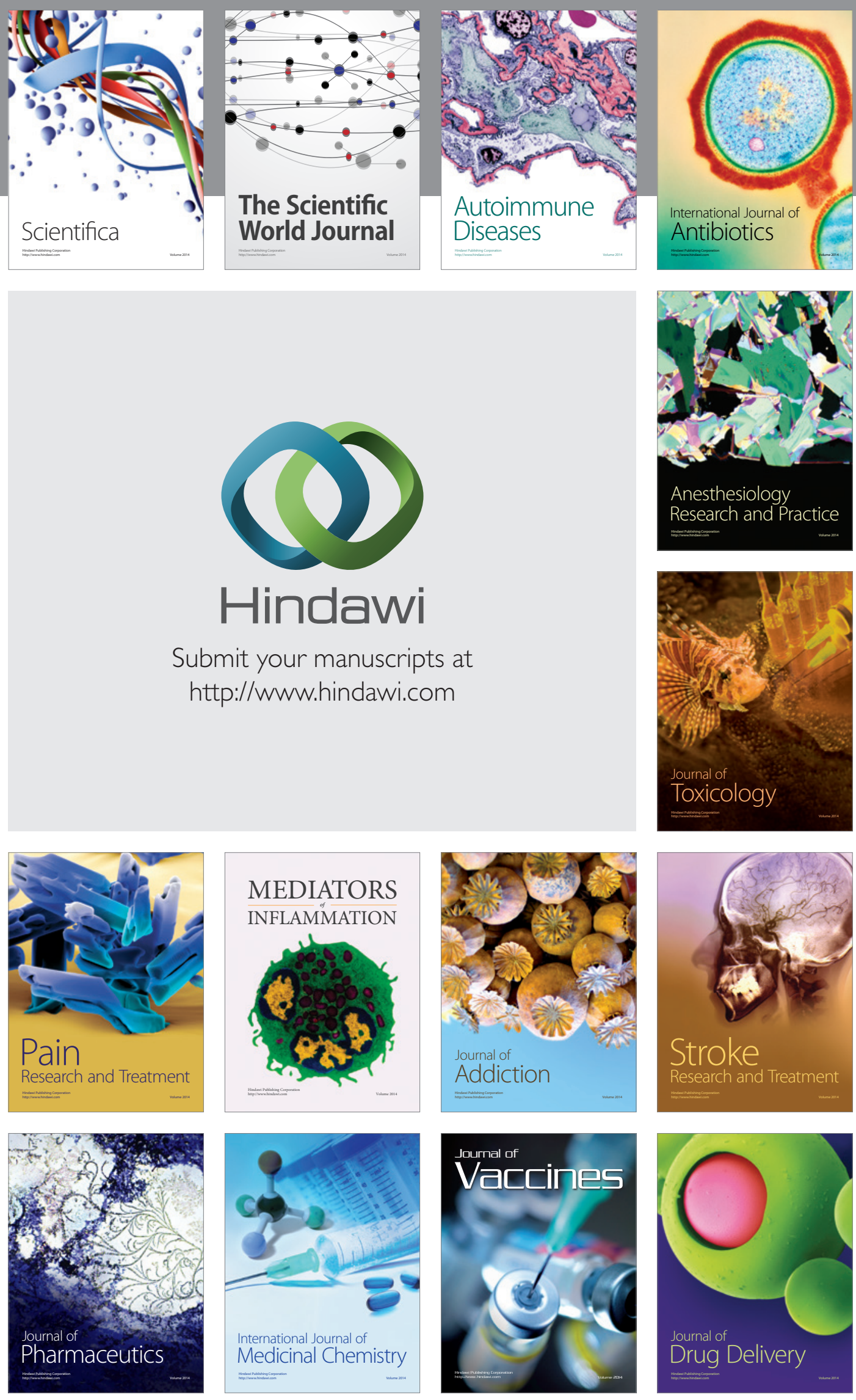